\title{
Sheep and Goat Grazing Effects on Three Atlantic Heathland Types
}

\author{
Berta M. Jáuregui, ${ }^{1}$ Urcesino García, ${ }^{2}$ Koldo Osoro, ${ }^{3}$ and Rafael Celaya ${ }^{1}$ \\ Authors are ${ }^{1}$ Research Associates, ${ }^{2}$ Experimental Farm Manager, and ${ }^{3}$ Research Head, Animal Production Systems Department, Servicio Regional de \\ Investigación y Desarrollo Agroalimentario, Apdo. 13, 33300 Villaviciosa, Asturias, Spain
}

\begin{abstract}
Heathlands in the northwest of Spain have been traditionally used by domestic herbivores as a food resource. However, their abandonment in the past decades has promoted a high incidence of wildfires, threatening biodiversity. Sheep and goats exhibit different grazing behavior, affecting rangelands dynamics in a different way, but the botanical and structural composition may also affect such dynamics. The aim of this article was to compare the grazing effects of sheep and goats on three different heathland types: previously burned grass- or gorse (Ulex gallii Planchon)-dominated and unburned heather (Erica spp.)dominated shrublands. Two grazing treatments (sheep or goats) were applied in each vegetation type in a factorial design with two replicates (12 experimental plots). A small fenced area was excluded from grazing in each plot (control treatment). The experiment was carried out from 2003 to 2006, and the grazing season extended from May to October-November. Plant cover, canopy height, and phytomass amount and composition were assessed in each plot. Results showed that goats controlled shrub encroachment, phytomass accumulation, and canopy height more than sheep in either burned grass- and gorse- and unburned heather-dominated shrublands. It was accompanied by a higher increase of herbaceous species under goat grazing. Nevertheless, plant dynamics showed different trends between the three vegetation types studied. Grazing effects were more important in previously burned grass-dominated heathlands than in unburned heather-dominated shrublands. At the end of the experiment (May 2006), shrub cover, height, and woody phytomass were significantly higher in the ungrazed enclosures than in the grazed plots. Small ruminant grazing, especially with goats, is proposed as an efficient tool to reduce shrub encroachment and woody phytomass accumulation in heathlands, thus reducing fire hazard, although these grazing effects depend on heathland composition.
\end{abstract}

\section{Resumen}

Los brezales-tojales en el noroeste de España han sido utilizados tradicionalmente por herbívoros domésticos como fuente de alimento. Sin embargo, su abandono en las últimas décadas está promoviendo una alta incidencia de incendios forestales, amenazando la biodiversidad. El ganado ovino y caprino muestra diferentes conductas de pastoreo, afectando la dinámica en los pastizales, pero la composición botánica y estructural también puede afectar dicha dinámica. El objetivo de este trabajo fue comparar los efectos del pastoreo del ganado ovino y caprino en tres diferentes tipos de brezales-tojales: pastizales previamente quemados dominados por vegetación herbácea (gramíneas) o por el tojo (Ulex gallii Planchon), y no quemados dominados por el brezo (Erica spp.). Dos tratamientos de pastoreo (ovino o caprino) fueron aplicados en cada tipo de vegetación en un diseño factorial con dos repeticiones (12 parcelas experimentales). Una pequeña área cercada fue excluida del pastoreo en cada parcela (tratamiento control). El experimento se realizó del 2003 al 2006, y la temporada de pastoreo se extendió de Mayo a OctubreNoviembre. Se evaluaron en cada parcela la cobertura vegetal, la altura del dosel, y la cantidad y composición de fitomasa. Los resultados mostraron que las cabras controlaron la invasión de arbustos, la acumulación de fitomasa y la altura del dosel más que las ovejas en cualquiera de los pastizales quemados de grama y tojo, y los pastizales no quemados dominados por el brezo. Lo que estuvo acompañado de un mayor incremento en especies de herbáceas bajo el pastoreo caprino. Sin embargo, la dinámica vegetal mostró diferentes tendencias entre los tres tipos de vegetación estudiados. Los efectos del pastoreo fueron más importantes en los brezales-tojales previamente quemados dominados por las gramíneas que en los matorrales no quemados dominados por el brezo. Al final del estudio (mayo 2006), la cobertura arbustiva, la altura y la biomasa de las leñosas fueron significativamente mayores en los matorrales sin pastoreo que en las parcelas pastadas. El pastoreo con pequeños rumiantes, especialmente con cabras, se propone como una herramienta eficiente para reducir la invasión de arbustos y la acumulación de fitomasa leñosa en los brezales-tojales reduciendo así el riesgo de incendios, aunque estos efectos del pastoreo dependen de la composición del brezal-tojal.

Key Words: gorse, heather, herbivory, plant succession, small ruminants

\section{INTRODUCTION}

Research was funded by the Spanish Interministerial Commission of Science and Technology (CICYT) under project AGL2003-05432. B.M.J. was funded by a grant from Spanish National Institute of Agricultural and Food Research and Technology (INIA).

Correspondence: Berta M. Jáuregui, Animal Production Systems Dept, Servicio Regional de Investigación y Desarrollo Agroalimentario (SERIDA), Ctra. de Oviedo s/n, Apdo. 13, 33300 Villaviciosa, Asturias, Spain. Email: berta7punto@yahoo.es

Manuscript received 24 October 2007; manuscript accepted 18 December 2008.
Heathlands are evergreen shrubland communities adapted to acidic soils and humid climate conditions and hence characteristic of western Atlantic Europe (Webb 1998). Heathlands are widespread in the northwest of Spain. In Asturias, heathlands occur on $21 \%$ of the total surface and have been traditionally used by the local population as a wood and 
hunting resource and by wild and domestic herbivores as a food resource (Álvarez et al. 2004). This vegetation is characterized by its low nutritive value for grazing livestock (Hodgson and Eadie 1986), as the dominant woody species generally have a low protein concentration and high levels of indigestible cell wall components (Celaya et al. 2007b; Osoro et al. 2007a).

Because of its low productivity, progressive abandonment of livestock grazing on heathlands in the past decades has led to high accumulations of woody phytomass, increasing fire incidence and endangering biodiversity (Ministerio de Medio Ambiente 2008). Appropriate management of livestock grazing in these communities should provide both environmental and economic benefits (Rook et al. 2004; Hadjigeorgiou et al. 2005). Osoro et al. (1999) suggested that sheep and goats are better adapted than cattle to the nutritionally poor vegetation of the heathlands.

The effects of sheep and goat grazing on heathlands are not always consistent in Europe. In northern heathlands, continuous herbivore overexploitation has endangered the stability and survival of these plant communities (Anderson and Yalden 1981; Thompson et al. 1995; Britton et al. 2005), whereas in the north of Spain, grazing with small ruminants has been proved to be an efficient tool for controlling shrub encroachment, decreasing woody phytomass and thus reducing fire hazard (Rigueiro-Rodríguez et al. 2005).

Foraging behavior of sheep and goats differ (Gordon 2003), the latter being a browser species well adapted to feed on shrubby vegetation, while sheep prefer to graze herbaceous species (Clark et al. 1982; Aldezabal 2001). Therefore, sheep and goat grazing can direct heathland succession toward different community composition and structure. Goats controlled encroachment of shrubs, such as heather and gorse species, more than sheep, promoting grass growth (Radcliffe 1986; Celaya et al. 2007a). Previous grazing history, fire, and environmental gradients can shift the outcome of vegetation succession (Vandvik et al. 2005).

We hypothesized that goats could control woody phytomass more effectively than sheep because of their tendency to browse. Shrub control could also be affected by initial botanical and structural composition and previous management (i.e., burning or grazing). The objective of this study was to compare effects of sheep and goat grazing on three different heathland types (grass, gorse, or heather dominated) and to assess how the initial composition affects vegetation successional trends under grazing.

\section{METHODS}

\section{Study Site}

The experimental field was located on the top of San Isidro Mountain, in the Asturias region of northwestern Spain (lat $43^{\circ} 21^{\prime} \mathrm{N}$, long $\left.6^{\circ} 53^{\prime} \mathrm{W}\right)$. Elevation at the site varied from 850 to $950 \mathrm{~m}$. Average annual temperature was $10.2^{\circ} \mathrm{C}$, with a mean temperature of $4.7^{\circ} \mathrm{C}$ in January and $16.8^{\circ} \mathrm{C}$ in August. Precipitation occurred mainly from October to January, with an annual mean of $1557 \mathrm{~mm}$ during 2002-2006.

The experimental field contained pronounced slopes and shallow soils. Soil pH (3.92) and concentrations of available calcium $(6 \mathrm{mg} / \mathrm{kg})$, magnesium $(25 \mathrm{mg} / \mathrm{kg})$, and phosphorus $(2 \mathrm{mg} / \mathrm{kg}$ ) were very low compared to more structured soils in the region.

The dominant plant community in this region is heathergorse, which occurs on $14 \%$ of the Asturias region (Álvarez et al. 2004). Vegetation occurring in the experimental field is an association Halimio alyssoidis-Ulicetum gallii (Díaz González and Fernández Prieto 1994). Heather species are Erica cinerea L., E. umbellata L., Calluna vulgaris (L.) Hull, and Daboecia cantabrica (Hudson) C. Koch. Gorse (Ulex gallii Planchon), a thorny woody legume, is also very common. Other characteristic woody species are Halimium alyssoides (Lam.) C. Koch, Genistella tridentata (L.) Samp, and Lithodora prostrata (Loisel.) Griseb. The most abundant herbaceous species are grasses such as Pseudarrhenatherum longifolium (Thore) Rouy and Agrostis curtisii Kerguélen.

\section{Experimental Design}

The study used a factorial design of two grazing treatments (sheep or goats) and three vegetation types (grass, gorse, or heather dominated) with two replicates. Two years before the experiment, in the spring of 2001, a heathland area of approximately 5 ha was superficially burned, and four adjacent 1.2-ha paddocks were established. Every second pasture was grazed during the autumn-winter (September-January) of 2001 and spring-autumn (May-October) of 2002 by sheep (randomly assigned) and every other field by goats, leading to gorse- or grass-dominated shrublands, respectively. In the spring of 2003, two surrounding unburned (heather dominated) areas were incorporated with the previously burned pastures for a total of six pastures: two burned and goat-grazed (grass dominated), two burned and sheep-grazed (gorse dominated), and two unburned and ungrazed (heather dominated). Each of the six pastures was divided into two fenced 0.6-ha paddocks. Sheep or goat grazing treatments were randomly assigned to paddocks. In addition, a $4 \times 4 \mathrm{~m}$ enclosure was fenced inside of each paddock to provide an ungrazed control. These enclosures were placed in the middle of the paddock to minimize nutrient fertilization by animal excretion.

Grazing began in May 2003 with four Gallega ewes (mean $\pm \mathrm{SE}, \quad 37.5 \pm 0.90 \mathrm{~kg}$ ) or four Cashmere goats $(34.4 \pm 0.84 \mathrm{~kg})$ in each paddock. Thus, stocking rate in 2003 was 6.7 animals $\cdot \mathrm{ha}^{-1}$, although it was increased to 10 animals $\cdot \mathrm{ha}^{-1}$ (six per paddock) in subsequent years (2004 and 2005). All animals were nonlactating adult females. Flocks grazed from May to October-November depending on weather conditions, except in 2005, when stock was removed at the end of August because of a severe summer drought $(33 \mathrm{~mm}$ rainfall during July-August compared to a mean of $127 \mathrm{~mm}$ during the same months in 2003, 2004, and 2006).

\section{Plant Sampling}

Botanical composition (relative species cover) and canopy height in the grazed plots were assessed using the point-quadrat method (Grant 1981). Three hundred vertical contacts were recorded along three permanent transects per plot from 2003 to 2006. Observations were recorded during May, August, and October 2003; May and October 2004; May, August, and October 2005; and May 2006. On the ungrazed control enclosures, plant cover and canopy height were determined 
Table 1. Initial plant cover, canopy height, and phytomass amount and composition in the three vegetation types studied (grass-, gorse-, and heather-dominated shrublands) prior to the establishment of sheep or goat grazing treatments $(N=12)$.

\begin{tabular}{|c|c|c|c|c|c|c|c|c|}
\hline & \multicolumn{2}{|c|}{ Grass dominated } & \multicolumn{2}{|c|}{ Gorse dominated } & \multicolumn{2}{|c|}{ Heather dominated } & \multirow[b]{2}{*}{ SEM } & \multirow[b]{2}{*}{$P$-value ${ }^{1}$} \\
\hline & Sheep & Goat & Sheep & Goat & Sheep & Goat & & \\
\hline \multicolumn{9}{|l|}{ Cover (\%) } \\
\hline Heather & 0.5 & 1.0 & 0.5 & 1.0 & 39.5 & 40.3 & 2.10 & $<0.001$ \\
\hline Gorse & 14.7 & 13.7 & 26.2 & 27.8 & 14.8 & 20.0 & 4.28 & 0.062 \\
\hline Other shrubs & 0.2 & 0.0 & 0.2 & 0.3 & 4.8 & 1.2 & 1.59 & 0.056 \\
\hline Herbaceous & 37.8 & 46.3 & 29.5 & 23.7 & 6.8 & 9.3 & 3.28 & $<0.001$ \\
\hline Dead matter & 34.8 & 34.0 & 34.2 & 33.2 & 32.5 & 27.3 & 2.02 & 0.129 \\
\hline Bare ground & 12.0 & 5.0 & 9.5 & 14.0 & 1.5 & 1.8 & 2.82 & 0.019 \\
\hline Height (cm) & 5.5 & 4.7 & 5.9 & 9.3 & 22.6 & 24.8 & 2.54 & $<0.001$ \\
\hline \multicolumn{9}{|l|}{ Phytomass } \\
\hline Total (kg dry matter $\cdot \mathrm{ha}^{-1}$ ) & 8524 & 8286 & 9982 & 13022 & 18421 & 19023 & 2781 & 0.025 \\
\hline Heather $\%$ & 18.9 & 27.4 & 11.1 & 15.2 & 70.7 & 69.5 & 3.98 & $<0.001$ \\
\hline Gorse \% & 51.4 & 43.9 & 67.6 & 72.2 & 17.1 & 17.4 & 5.45 & $<0.001$ \\
\hline Other shrubs \% & 0.1 & 0.2 & 0.0 & 0.2 & 4.0 & 3.0 & 1.72 & 0.074 \\
\hline Herbaceous \% & 29.6 & 28.5 & 21.2 & 12.5 & 8.2 & 10.1 & 3.22 & 0.002 \\
\hline
\end{tabular}

${ }^{1} P$-value for difference among vegetation treatments (grass dominated, gorse dominated, and heather dominated). Livestock and the livestock $\times$ vegetation interaction were not important sources of variation for all variables $(P>0.10)$.

using the same method at random 50 vertical contacts per enclosure in June 2006.

Aerial phytomass was harvested in five randomly located quadrats of $0.2 \times 1 \mathrm{~m}$ per plot using pruning shears. Samples were sorted into four botanical components: heather species ( $E$. cinerea, E. umbellata, C. vulgaris, D. cantabrica), gorse (U. gallii), other shrubs (G. tridentata, H. alyssoides, L. prostrata), and herbaceous species (mainly the grasses $P$. longifolium and A. curtisii). Samples were dried in a forced-air oven at $80^{\circ} \mathrm{C}$ for $24 \mathrm{~h}$ and weighed as dry matter (DM). Field sampling was conducted in May, August, and November 2003, June and October 2004, June and August 2005, and June 2006. Ungrazed control enclosures were sampled at the end of the experiment (June 2006) by cutting phytomass in one randomly allocated quadrat of $0.2 \times 1 \mathrm{~m}$ in each enclosure.

Data from the four control enclosures in each vegetation type were pooled (200 point-quadrat contacts and four phytomass quadrats) for the analyses because of their smaller size.

\section{Statistical Analysis}

Initial (May 2003) pretreatment differences in plant cover, canopy height, and phytomass data were examined by factorial two-way analysis of variance (ANOVA) for the main effects of vegetation type (grass-, gorse-, or heather-dominated shrubland) and livestock species (sheep or goat) and their interaction.

Vegetation data during the experiment (2003-2006) were evaluated using a mixed model for repeated measures with the PROC MIXED procedure (Littell et al. 1998; SAS Institute 1999). Cover and height were measured nine times, and phytomass was measured eight times. The model included livestock species $(\mathrm{L})$, vegetation type $(\mathrm{V})$, sampling time $(\mathrm{T})$, and the $\mathrm{L} \times \mathrm{V}, \mathrm{L} \times \mathrm{T}, \mathrm{V} \times \mathrm{T}$, and $\mathrm{L} \times \mathrm{V} \times \mathrm{T}$ interactions as fixed effects. Paddocks were the experimental units and used as subjects in the repeated measurements analysis. Different modeling approaches (compound symmetry [CS], heteroge- neous CS, antedependence, Toeplitz, heterogeneous Toeplitz) were fitted to the covariance structure, and the best model for each dependent variable was selected according to the finitesample corrected Akaike information criterion (Littell et al. 1998; Wang and Goonewardene 2004). Some of the dependent variables showed variance heterogeneity among vegetation types (e.g., heather cover percentage). In that case, a group effect was specified to set a covariance structure for each vegetation type (SAS Institute 1999). A Tukey test was used to examine pairwise differences between vegetation type means.

Vegetation data at the end of the experiment (May-June 2006) were analyzed with factorial two-way ANOVA to test for the differences between sheep, goats, and no grazing (control enclosures) and their interactions with vegetation type, checking post hoc mean differences with a Tukey test. The smaller size of the control enclosures (one $4 \times 4 \mathrm{~m}$ fenced enclosure per paddock) necessitated a smaller sample and reduced accuracy compared to grazed paddocks. Correspondingly data from enclosures were pooled for each vegetation type (four enclosures) prior to analyses. Percentage data (cover and phytomass) were angular transformed before performing the analyses (Zar 1999).

\section{RESULTS}

At the beginning of the experiment (May 2003), botanical composition (cover), canopy height, and phytomass differed $(P<0.05)$ between vegetation types (Table 1$)$. At that time, no differences $(P>0.10)$ were found between grazing treatments.

\section{Vegetation Cover}

After pooling the three vegetation types, shrub cover (live plants) increased from $34 \pm 8.4 \%$ in May 2003 to $55 \pm 2.1 \%$ in May 2006 under sheep grazing, while it increased from $35 \pm 8.9 \%$ to $39 \pm 3.2 \%$ under goat grazing $(P<0.001)$. Given the initial differences between vegetation types, shrub cover 
Table 2. Effects of livestock species (L), vegetation type (V), time (T), and their interactions on plant cover, canopy height, and phytomass $(N=12)$.

\begin{tabular}{|c|c|c|c|c|c|c|c|c|c|c|c|c|c|c|}
\hline & \multicolumn{2}{|c|}{ Grass dominated } & \multicolumn{2}{|c|}{ Gorse dominated } & \multicolumn{2}{|c|}{ Heather dominated } & \multirow[b]{2}{*}{ SEM } & \multicolumn{7}{|c|}{$P$-values } \\
\hline & Sheep & Goat & Sheep & Goat & Sheep & Goat & & L & V & $L \times V$ & $\mathrm{~T}$ & $\mathrm{~L} \times \mathrm{T}$ & $V \times T$ & $\mathrm{~L} \times \mathrm{V} \times \mathrm{T}$ \\
\hline \multicolumn{15}{|l|}{ Cover (\%) } \\
\hline Total shrubs & 36.0 & 27.5 & 48.8 & 39.7 & 59.2 & 54.5 & 2.86 & 0.002 & $<0.001$ & 0.717 & $<0.001$ & $<0.001$ & $<0.001$ & 0.110 \\
\hline Heather & 0.9 & 1.3 & 1.0 & 1.6 & 40.3 & 36.7 & 2.97 & 0.535 & $<0.001$ & 0.474 & 0.006 & 0.088 & $<0.001$ & 0.012 \\
\hline Gorse & 35.0 & 26.2 & 47.6 & 38.1 & 15.2 & 17.0 & 4.14 & 0.108 & $<0.001$ & 0.315 & $<0.001$ & $<0.001$ & $<0.001$ & 0.013 \\
\hline Other shrubs & 0.0 & 0.0 & 0.1 & 0.1 & 3.7 & 0.8 & 1.10 & 0.271 & 0.074 & 0.319 & 0.006 & 0.374 & 0.018 & 0.666 \\
\hline Herbaceous & 18.4 & 33.4 & 15.9 & 17.4 & 5.4 & 10.1 & 2.98 & $<0.001$ & $<0.001$ & $<0.001$ & $<0.001$ & $<0.001$ & $<0.001$ & 0.091 \\
\hline Dead matter & 31.3 & 34.7 & 29.0 & 32.4 & 33.8 & 32.8 & 1.23 & 0.057 & 0.082 & 0.138 & $<0.001$ & 0.153 & $<0.001$ & 0.114 \\
\hline Bare ground & 14.4 & 4.4 & 6.3 & 10.5 & 1.6 & 2.6 & 1.73 & 0.394 & $<0.001$ & 0.003 & 0.253 & 0.102 & 0.001 & 0.434 \\
\hline Height (cm) & 10.0 & 7.3 & 12.1 & 13.5 & 22.5 & 21.8 & 2.52 & 0.766 & $<0.001$ & 0.717 & $<0.001$ & 0.002 & $<0.001$ & 0.119 \\
\hline \multicolumn{15}{|l|}{ Phytomass } \\
\hline $\begin{array}{l}\text { Total }(\mathrm{kg} \text { dry } \\
\left.\text { matter } \cdot \mathrm{ha}^{-1}\right)\end{array}$ & 11213 & 10116 & 14482 & 12863 & 21464 & 19512 & 1634 & 0.250 & $<0.001$ & 0.966 & $<0.001$ & 0.102 & 0.155 & 0.302 \\
\hline Heather \% & 18.3 & 12.1 & 7.6 & 12.0 & 65.9 & 67.8 & 6.20 & 0.988 & $<0.001$ & 0.211 & 0.006 & 0.366 & 0.316 & 0.601 \\
\hline Gorse \% & 63.5 & 50.5 & 77.7 & 74.6 & 23.4 & 20.1 & 3.86 & 0.053 & $<0.001$ & 0.506 & $<0.001$ & 0.050 & 0.262 & 0.996 \\
\hline Other shrubs \% & 0.0 & 0.0 & 0.0 & 0.1 & 5.1 & 1.5 & 1.83 & 0.595 & 0.032 & 0.730 & 0.989 & 0.489 & 0.998 & 0.674 \\
\hline Herbaceous \% & 18.1 & 37.4 & 14.7 & 13.3 & 5.6 & 10.6 & 3.05 & $<0.001$ & $<0.001$ & 0.001 & 0.001 & $<0.001$ & 0.719 & 0.007 \\
\hline
\end{tabular}

increased during the experimental period in both burned grassand gorse-dominated vegetation (from $15 \pm 1.9 \%$ to $40 \pm 5.7 \%$ and from $28 \pm 1.6 \%$ to $48 \pm 5.1 \%$, respectively) but decreased in unburned heather-dominated (from $60 \pm 2.7 \%$ to $52 \pm 3.9 \% ; P<0.001$ for vegetation type $\times$ time interaction; Table 2).

Little heather presence was observed in burned plots (Table 2). In unburned plots, its heather cover decreased slightly under sheep grazing (from $39 \pm 3.2 \%$ in 2003 to $36 \pm 2.5 \%$ in 2006), while a more marked decrease was observed under goat grazing (from $40 \pm 4.0 \%$ to $32 \pm 3.2 \%$; $P<0.05$ for livestock species $\times$ time interaction).

Gorse cover increased more $(P<0.001)$ under sheep (from $19 \pm 2.6 \%$ to $40 \pm 7.6 \%$ ) than under goat grazing (from $20 \pm 2.6 \%$ to $25 \pm 4.9 \%$ ) and in burned than in unburned plots $(P<0.001)$. The differences between sheep and goats were higher in the burned plots $(P<0.05$ for livestock species $\times$ vegetation $\times$ time interaction; Fig. 1$)$.

Presence of other shrubs (G. tridentata, $H$. alyssoides, $L$. prostrata) was negligible in burned plots $(<0.5 \%$ cover $)$. In the unburned plots, their mean cover varied $(P<0.01)$ from $3.0 \pm 1.9 \%$ in 2003 to $2.2 \pm 1.4 \%$ in $2004-2005$ and to $3.6 \pm 1.9 \%$ in 2006 without differences $(P>0.10)$ between grazing treatments.

Inversely to woody species, cover of live herbaceous plants decreased more $(P<0.001)$ under sheep grazing (from $25 \pm 6.1 \%$ in 2003 to $12 \pm 2.2 \%$ in 2006) than under goat grazing (from $26 \pm 6.9 \%$ to $24 \pm 4.5 \%$ ). In all vegetation types, treatments, and years, herbaceous cover decreased from spring to autumn, showing differences $(P<0.001)$ between vegetation types over time (Fig. 2).

Inversely to live plants, dead matter cover increased from spring to autumn $(P<0.001$; Table 2$)$. In burned plots, cover of dead matter decreased across years, while in unburned heather-dominated plots, it increased $(P<0.001$ for time $\times$ vegetation type interaction; Table 2$)$. The percentage of bare ground decreased during the experiment in gorse-dominated, remained nearly constant in grass-dominated, and increased in heather-dominated vegetation $(P<0.001)$, with no differences $(P>0.10)$ between livestock species (Table 2$)$.

At the end of the experimental period (May 2006), cover of all examined botanical components, except for other shrubs, differed between sheep, goat, and no-grazing treatments $(P<0.01)$. Vegetation type also affected $(P<0.05)$ all variables except dead matter and bare ground (Table 3$)$. Heather cover was greater $(P<0.001)$ in the ungrazed enclosures $(27 \pm 14.2 \%)$ than in sheep or goat-grazed plots $(13 \pm 4.5 \%)$. Gorse accounted for $61 \pm 13.5 \%$ cover in the ungrazed enclosures compared to $40 \pm 7.6 \%$ under sheep and $25 \pm 4.9 \%$ under goat grazing $(P<0.01)$. Conversely, cover of herbaceous plants was lower $(P<0.01)$ in the ungrazed enclosures $(2 \pm 1.4 \%)$ than in sheep $(12 \pm 2.2 \%)$ and goat-grazed plots $(24 \pm 4.6 \%)$. Dead matter and bare ground percentages were lower in ungrazed than in grazed plots $(P<0.001)$.

\section{Canopy Height}

After pooling the three vegetation types, mean canopy height increased more $(P<0.01)$ over time under sheep (from $11.3 \pm 3.6 \mathrm{~cm}$ in 2003 to $17.3 \pm 1.6 \mathrm{~cm}$ in 2006) than under goat grazing (from $12.9 \pm 4.1 \mathrm{~cm}$ to $14.7 \pm 2.2 \mathrm{~cm}$ ). In general, it increased from year to year in both grass- and gorsedominated plots, whereas it decreased in heather-dominated plots $(P<0.001$; Fig. 3$)$. At the end of the experiment, canopy height was higher $(P<0.001)$ in ungrazed plots $(41.4 \pm 1.9 \mathrm{~cm})$ than in grazed plots $(16.0 \pm 1.4 \mathrm{~cm}$; Table 3$)$.

\section{Phytomass}

During the experimental period, phytomass was greater in unburned heather-dominated vegetation than in burned gorseand grass-dominated vegetation (20488, 13673, and $10664 \mathrm{~kg} \mathrm{DM} \cdot \mathrm{ha}^{-1}$, respectively; SEM $=1155 ; \mathrm{P}<0.001$; Table 2). After pooling vegetation types, phytomass tended to increase over time under sheep grazing (from 
A) Grass-dominated

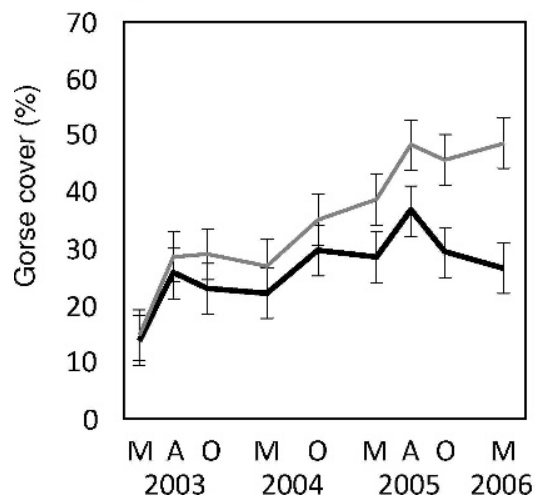

B) Gorse-dominated

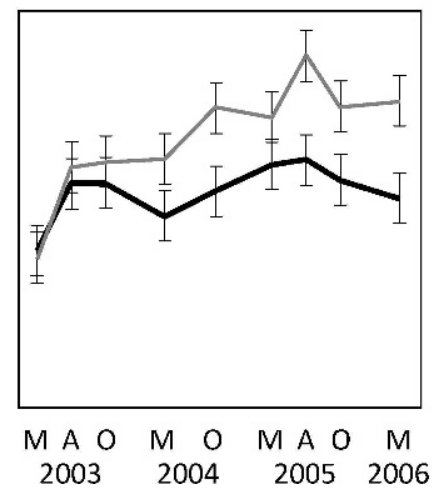

C) Heather-dominated

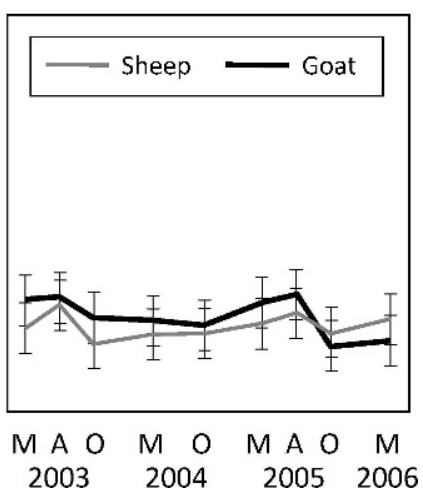

Figure 1. Changes in gorse cover (least squares means \pm SEM) from 2003 to 2006 under sheep or goat grazing on (A) grass-, (B) gorse-, and (C) heather-dominated shrublands (M: May; A: August; 0: October).

$12309 \pm 2265 \mathrm{~kg} \mathrm{DM} \cdot \mathrm{ha}^{-1}$ in May 2003 to $15854 \pm 2050$ $\mathrm{kg} \mathrm{DM} \cdot \mathrm{ha}^{-1}$ in June 2006), while a decreasing trend was found under goat grazing (from $13444 \pm 2373 \mathrm{~kg} \mathrm{DM} \cdot \mathrm{ha}^{-1}$ to $11457 \pm 1764 \mathrm{~kg} \mathrm{DM} \cdot \mathrm{ha}^{-1} ; P=0.102 ;$ Fig. 4$)$. Woody phytomass (heather, gorse, and other shrubs all together) increased more under sheep (from $10316 \pm 2402 \mathrm{~kg}$ $\mathrm{DM} \cdot \mathrm{ha}^{-1}$ in 2003 to $14918 \pm 1998 \mathrm{~kg} \mathrm{DM} \cdot \mathrm{ha}^{-1}$ in 2006) than under goat grazing (from $11541 \pm 2459 \mathrm{~kg} \mathrm{DM} \cdot \mathrm{ha}^{-1}$ to $\left.9459 \pm 2057 \mathrm{~kg} \mathrm{DM} \cdot \mathrm{ha}^{-1} ; P<0.05\right)$.

With regard to phytomass composition, the proportion of heather was as expected higher in heather-dominated plots $(67 \%)$ than in grass- $(15 \%)$ and gorse-dominated plots $(10 \%$; SEM $=4.4 ; \quad P<0.001$ ); it decreased over time (from $35 \pm 7.6 \%$ in 2003 to $29 \pm 8.9 \%$ in $2006 ; P<0.01)$ with no $(P>0.10)$ treatment or vegetation type effects (Table 2$)$. Gorse made up $76 \%, 57 \%$, and $22 \%$ of the total phytomass in gorse-, grass-, and heather-dominated vegetation, respectively (SEM = $2.7 ; P<0.001)$, and increased more over time under sheep (from $45 \pm 9.8 \%$ to $61 \pm 12.6 \%$ ) than under goat grazing (from $44 \pm 10.2 \%$ to $50 \pm 10.3 \% ; P=0.05$ ). Other shrubs accounted for small percentages of total phytomass, being higher $(P<0.05)$ in heather-dominated plots $(3.3 \%)$ than in burned plots $(<0.5 \%$; SEM $=1.40)$. The proportion of herbaceous phytomass was higher in grass- $(28 \%)$ than in gorse- $(14 \%)$ and heather-dominated vegetation $(8 \%$; SEM $=$ $1.7 ; P<0.001$ ); it increased over time under goat grazing (from $17 \pm 3.8 \%$ to $22 \pm 7.2 \%$ ) and decreased under sheep grazing (from $20 \pm 4.3 \%$ to $6 \pm 1.1 \%, P<0.001$ ), with the greatest differences arising in the grass-dominated vegetation $(P<0.01$ for time $\times$ treatment $\times$ vegetation interaction; Fig. 4).

At the end of the study (June 2006), total phytomass was greater in ungrazed than in grazed plots $(27675 \pm 2714 \mathrm{~kg}$ $\mathrm{DM} \cdot \mathrm{ha}^{-1}$ and $13655 \pm 1450 \mathrm{~kg} \mathrm{DM} \cdot \mathrm{ha}^{-1}$, respectively; $P<0.01)$. No differences between grazing treatments were found in the percentages of heather, gorse, or other shrubs $(P>0.10)$. The proportion of herbaceous phytomass was affected by the treatment $\times$ vegetation type interaction $(P<0.001)$. In grass-dominated vegetation, such percentage was much higher $(P<0.001)$ in goat-grazed plots $(45.0 \%)$ than in sheep-grazed and ungrazed plots $(7.9 \%$ and $12.1 \%$, respectively; SEM $=1.55$ ). Lower differences between goat and sheep treatments were found both in heather- $(8.2 \%$ vs. $2.8 \% ; \mathrm{SEM}=1.09 ; P<0.05)$ and in gorse-dominated vegetation $(14.2 \%$ vs. $8.0 \%$; $\mathrm{SEM}=1.09 ; P=0.105)$. In these two vegetation types, intermediate herbaceous percentage values were observed in ungrazed plots, and consequently no differences $(P>0.05)$ between any grazing treatments were observed.

\section{A) Grass-dominated}

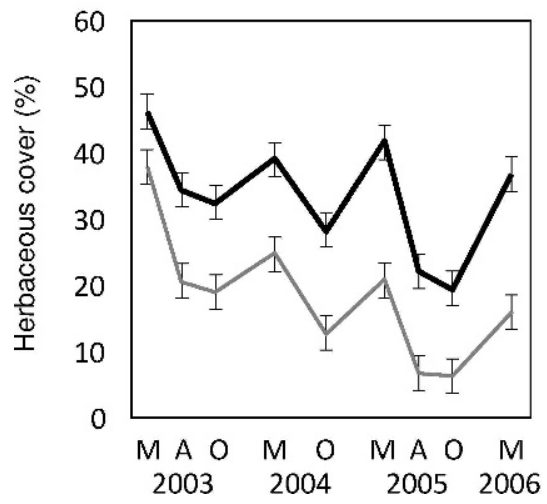

B) Gorse-dominated

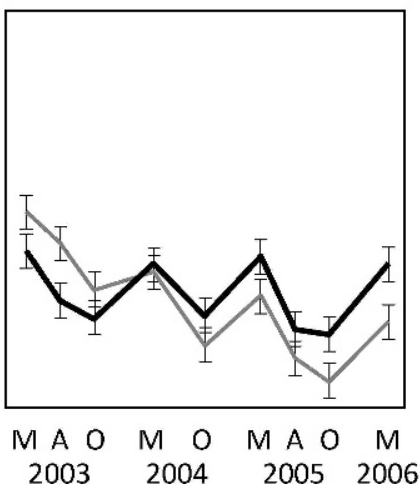

\section{C) Heather-dominated}

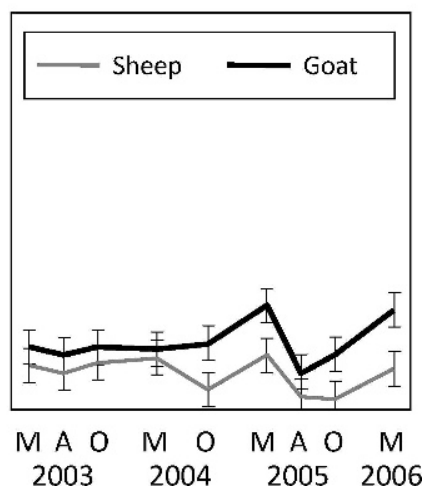

Figure 2. Changes in herbaceous cover (least squares means \pm SEM) from 2003 to 2006 under sheep or goat grazing on (A) grass-, (B) gorse-, and (C) heather-dominated shrublands (M: May; A: August; 0: October). 
Table 3. Effects of grazing treatment ( $T r$; sheep, goat, or no grazing) and vegetation type (V; grass, gorse, or heather dominated) on plant cover and canopy height at the end of the experiment $(N=15){ }^{1}$

\begin{tabular}{|c|c|c|c|c|c|c|c|c|c|c|c|c|}
\hline & \multicolumn{3}{|c|}{ Grass dominated } & \multicolumn{3}{|c|}{ Gorse dominated } & \multicolumn{3}{|c|}{ Heather dominated } & \multirow[b]{2}{*}{ SEM } & \multicolumn{2}{|c|}{$P$-values } \\
\hline & Sheep & Goat & Ungrazed & Sheep & Goat & Ungrazed & Sheep & Goat & Ungrazed & & $\mathrm{Tr}$ & V \\
\hline \multicolumn{13}{|l|}{ Cover (\%) } \\
\hline Gorse & 48.5 & 26.8 & 66.5 & 54.0 & 36.8 & 80.5 & 16.0 & 12.7 & 35.0 & 5.50 & 0.001 & $<0.001$ \\
\hline Other shrubs & 0.0 & 0.0 & 0.5 & 0.3 & 0.0 & 0.0 & 5.5 & 1.7 & 3.0 & 2.23 & 0.432 & 0.010 \\
\hline Herbaceous & 16.2 & 36.8 & 5.0 & 12.8 & 21.7 & 1.5 & 6.2 & 14.8 & 0.5 & 5.10 & 0.001 & 0.023 \\
\hline Bare ground & 11.3 & 4.2 & 0.0 & 5.7 & 9.0 & 0.0 & 2.5 & 3.8 & 0.0 & 2.39 & $<0.001$ & 0.115 \\
\hline Height (cm) & 14.0 & 9.5 & 39.7 & 16.5 & 15.8 & 45.2 & 21.3 & 18.9 & 39.2 & 3.62 & $<0.001$ & 0.126 \\
\hline
\end{tabular}

${ }^{1}$ The grazing treatment $\times$ vegetation type interaction was not an important source of variation for all variables $(P>0.05)$.

\section{DISCUSSION}

Goats were able to control shrub encroachment better than sheep on grass-, gorse-, or heather-dominated vegetation. These results agree with those obtained in partially improved paddocks located in the same experimental farm and managed with other breeds of sheep (Gallega), goats (Celtiberic), or mixed flocks on both previously untreated or mechanically cleared heathland areas (Celaya et al. 2007a). In the previously mentioned work, differences in the dynamics of woody plants between the three flock types were restricted mainly to gorse rather than to heather. In addition, in the current study, differences between sheep and goats were greater on previously burned paddocks, with gorse as the dominant shrub, than on unburned paddocks dominated by heather species. A greater control of Ulex europaeus by goats than by sheep was also observed in Galicia, northwest Spain (Sineiro 1982), and New Zealand (Radcliffe 1986). A direct consequence of the greater control of the shrubs and particularly of gorse in the paddocks grazed by goats was the increased abundance (cover, height, and mass) of grasses compared to sheep-grazed plots, similar to that observed in the previously mentioned works. Shrub control is known to increase the availability of soil nutrients and light for herbaceous species (Clément and Touffet 1990; Peltzer and Köchy 2001).

The differences found between sheep and goat grazing in heathland dynamics are likely the result of their different grazing behavior. Celaya et al. (2007b) observed higher percentages of gorse in goat diets than in sheep diets across the grazing season. Similarly, in different scrub-pasture associations of New Zealand including burned shrublands, a higher diet selection of gorse (U. europaeus) by goats than by sheep was observed (Clark et al. 1982; Radcliffe 1986). Differences between sheep and goats for heather selection have been found to be lower than for gorse in Spanish heathlands (Bartolomé et al. 1998; Celaya et al. 2007b).

Nevertheless, sheep grazing reduced shrub cover, height, and mass compared to the ungrazed enclosures. Increases in sheep stocking density lead to reductions in heather cover (Anderson and Yalden 1981; Alonso et al. 2001), though the intensity or extent of such effect is also affected by season and length of grazing (Grant et al. 1982; Gallet and Roze 2001).

Independent of livestock species, plant dynamics also differed between the studied vegetation types, mainly between burned and unburned vegetation. Fire is known to strongly affect species composition in heathlands (Hobbs and Gimingham 1987; Vandvik et al. 2005). In the present work, shrub cover and canopy height increased over time on both burned grass- and gorse-dominated vegetation, whereas they decreased on unburned heather-dominated paddocks, suggesting that grazing effects on vegetation depend on the successional stage of the plant community (Hobbs and Gimingham 1987; Welch and Scott 1995), which in turn affects the grazing behavior of small ruminants (Baumont et al. 2000). In addition, trampling
A) Grass-dominated

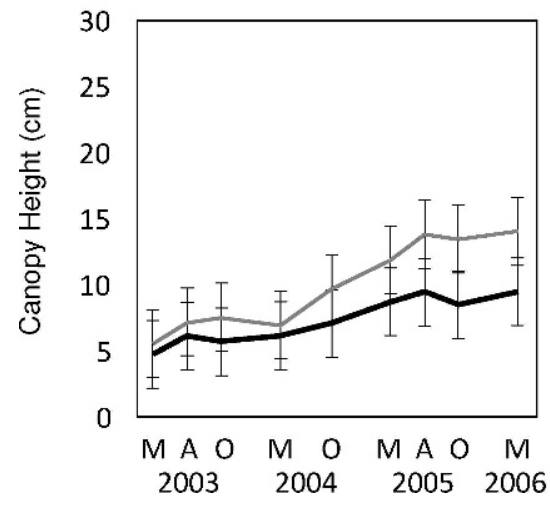

B) Gorse-dominated

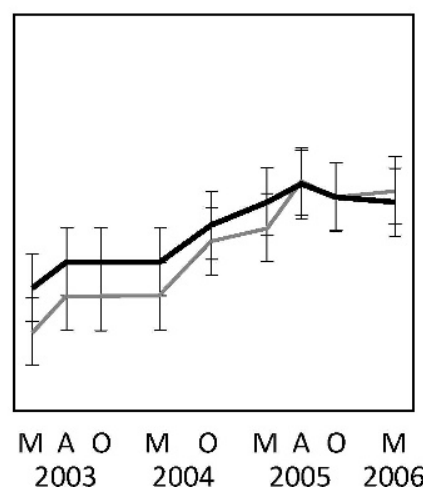

C) Heather-dominated

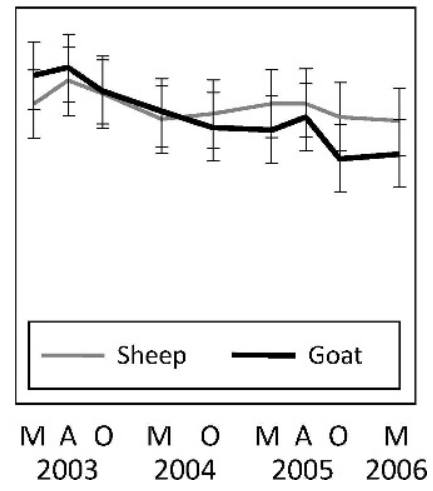

Figure 3. Changes in canopy height (least squares means \pm SEM) from 2003 to 2006 under sheep or goat grazing on (A) grass-, (B) gorse-, and (C) heather-dominated shrublands (M: May; A: August; 0: October). 


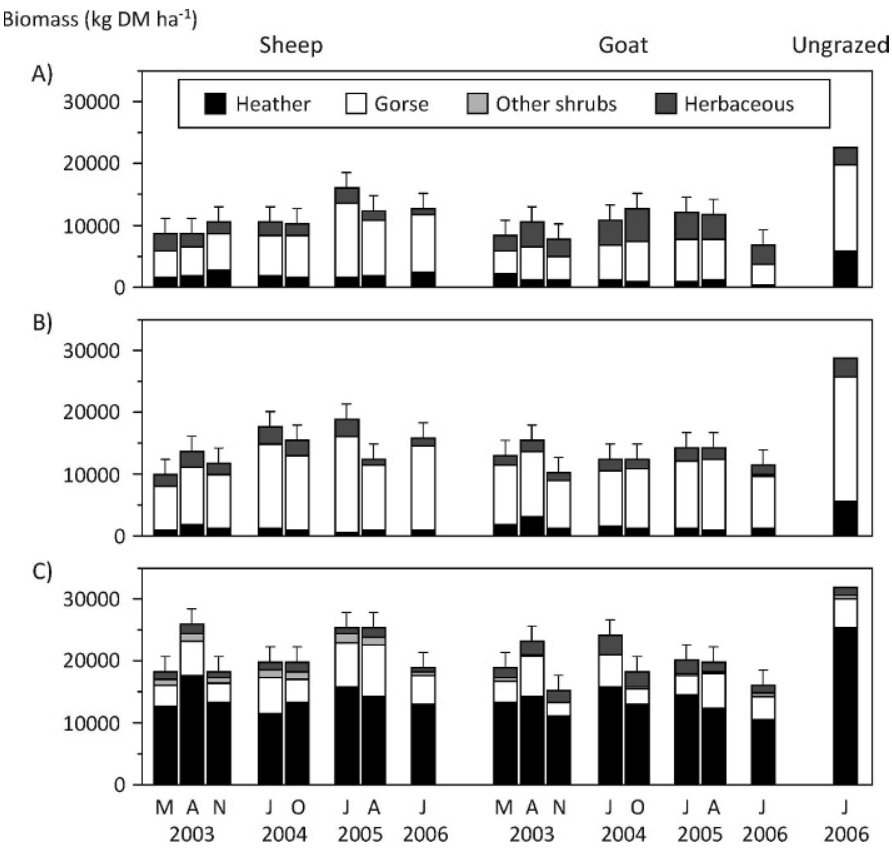

Figure 4. Changes in phytomass amount and composition from 2003 to 2006 under sheep or goat grazing on (A) grass-, (B) gorse-, and (C) heather-dominated shrublands (M: May; J: June; A: August; 0: October; $\mathrm{N}$ : November). Phytomass accumulation in the ungrazed enclosures in 2006 is shown. Vertical bars show SEM for total phytomass.

effects on shrub cover were presumably more pronounced in heather-dominated vegetation than in previously burned grassor gorse-dominated vegetation.

Although goat grazing reduced gorse encroachment, promoting a higher herbaceous presence in the burned shrublands, sustainability of such management would be very limited in terms of livestock production because of the low nutritive value of available vegetation. New spring shoots of gorse have high protein content, but protein levels quickly decrease during summer (Celaya et al. 2007b), together with a thorn hardening that limits animal intake and mobility. Palatability and nutrient content of native grasses growing in these shrublands is also quite low, and thus animal nutritive requirements would not be fully satisfied in burned shrublands even in nonlactating animals, as proved by their negative live-weight changes for most of the grazing season (B. M. Jáuregui, U. García, K. Osoro, and R. Celaya, unpublished data, 2003-2006). Furthermore, this gorse-dominated vegetation represents a high risk for recurrent fires (Núñez-Regueira et al. 1996). On the other hand, the scarce presence of heather after burning could negatively affect goat performance. Sheep and goats prefer heather rather than gorse for most of the grazing season (Celaya et al. 2007b). It has been recently observed that tannincontaining heather has anthelmintic properties in goats, reducing parasitic infection and improving animal welfare and performance (Osoro et al. 2007b).

\section{IMPLICATIONS}

Goats were more efficient than sheep as a management tool to control an excessive accumulation of woody combustible material and enhance the herbaceous cover, which should reduce fire risk. Nevertheless, such control depended on the initial composition of the vegetation. Goat grazing was more effective at early successional stages after a fire. In previously burned heathlands, the control of gorse encroachment by goats declines once gorse plants develop thick stems and hard thorns. Gorse can attain dominance after few years in the absence of grazing or even under sheep grazing.

\section{ACKNOWLEDGMENTS}

We would like to thank the staff of the experimental farm "El Carbayal" for their collaboration in the study as well as to the personnel of the laboratory for their contribution in sample preparation.

\section{LITERATURE CITED}

Aldezabal, A. 2001. El sistema de pastoreo del Parque Nacional de Ordesa y Monte Perdido (Pirineo central, Aragón): interacción entre la vegetación supraforestal y los grandes herbívoros. Zaragoza, Spain: Consejo de Protección de la Naturaleza de Aragón. 317 p.

Alonso, I., S. E. Hartley, and M. Thurlow. 2001. Heather-grass competition on Scottish moorlands: interacting effects of nutrient enrichment and grazing regime. Journal of Vegetation Science 12:249-260.

Álvarez, M. A., P. García, and J. Valderrábano. 2004. Tipificación, cartografía y evaluación de los pastos españoles: cartografía de los pastos de Asturias. Available at: http://www.indurot.uniovi.es:8081/Bibliotecas/publicos/subsitio/ default.aspx. Accessed 7 July 2008.

Anderson, P., And D. W. Yalden. 1981. Increased sheep numbers and the loss of heather moorland in the Peak District, England. Biological Conservation 20:195-213.

Bartolomé, J., J. Franch, J. Plaixats, and N. G. Seligman. 1998. Diet selection by sheep and goats on Mediterranean heath-woodland range. Journal of Range Management 51:383-391.

Baumont, R., S. Prache, M. Meuret, and P. Morand-Fehr. 2000. How forage characteristics influence behaviour and intake in small ruminants: a review. Livestock Production Science 64:15-28.

Britton, A. J., I. S. K. PeArce, and B. Jones. 2005. Impacts of grazing on montane heath vegetation in Wales and implications for the restoration of montane areas. Biological Conservation 125:515-524.

Celaya, R., A. Martínez, and K. Osoro. 2007a. Vegetation dynamics in Cantabrian heathlands associated with improved pasture areas under single or mixed grazing by sheep and goats. Small Ruminant Research 72:165-177.

Celaya, R., M. Oliván, L. M. M. Ferreira, A. Martínez, U. García, and K. Osoro. 2007b. Comparison of grazing behaviour, dietary overlap and performance in nonlactating domestic ruminants grazing on marginal heathland areas. Livestock Science 106:271-281.

Clark, D. A., M. G. Lambert, M. P. Rolston, and N. Dymock. 1982. Diet selection by goats and sheep on hill country. Proceedings of the New Zealand Society of Animal Production 42:155-157.

Clément, B., And J. Touffet. 1990. Plant strategies and secondary succession on Brittany heathlands after severe fire. Journal of Vegetation Science 1:195-202.

Díaz González, T. E., and J. A. Fernández Prieto. 1994. La vegetación de Asturias. Itinera Geobotanica 8:243-528.

Gallet, S., and F. Roze. 2001. Conservation of heathland by sheep grazing in Brittany (France): importance of grazing period on dry and mesophilous heathlands. Ecological Engineering 17:333-344.

GoRdon, I. 2003. Browsing and grazing ruminants: are they different beasts? Forest Ecology and Management 181:13-21.

Grant, S. A. 1981. Sward components. In: J. Hodgson, R. D. Baker, A. Davies, A. S. Laidlaw, and J. D. Leaver [EDS.]. Sward measurement handbook. Hurley, Maidenhead, Berkshire, United Kingdom: British Grassland Society. p. 71-92. 
Grant, S. A., J. A. Milne, G. T. Barthram, and W. G. Souter. 1982. Effects of season and level of grazing on the utilization of heather by sheep. 3. Longer-term responses and sward recovery. Grass and Forage Science 37:311-320.

Hadjigeorgiou, I., K. Osoro, J. P. Fragoso De Almeida, and G. Molle. 2005. Southern European grazing lands: production, environmental and landscape management aspects. Livestock Production Science 96:51-59.

HobBS, R. J., AND C. H. Gimingham. 1987. Vegetation, fire and herbivore interactions in heathland. Advances in Ecological Research 16:87-173.

Hodgson, J., AND J. EAdIE. 1986. Vegetation resources and animal nutrition in hill areas: agricultural and environmental implications. In: M. A. O'Toole [ED.]. Hill Land Symposium; 10-15 May 1984; Galway, Ireland. Dublin, Ireland: An Foras Talúntais. p. 118-133

Littell, R. C., P. R. Henry, and C. B. Ammerman. 1998. Statistical analysis of repeated measures data using SAS procedures. Journal of Animal Science 76:1216-1231.

Ministerio de Medio Ambiente. 2008. Incendios forestales en España. Available at: http://www.mma.es/secciones/biodiversidad/defensa_incendios/estadisticas_ incendios/pdf/Avance Informativo_2007.pdf. Accessed 7 July 2008.

Núnezz-Regueira, L., J. A. Rodríguez Añón, and J. Proupín Castiñeiras. 1996. Calorific values and flammability of forest species in Galicia: coastal and hillside zones. Bioresource Technology 57:283-289.

Osoro, K., U. García, B. M. Jáuregui, L. M. M. Ferreira, A. J. Rook, and R. Celaya. 2007a. Diet selection and live-weight changes of two breeds of goats grazing on heathlands. Animal 1:449-457.

Osoro, K., A. Mateos-Sanz, P. Frutos, U. García, L. M. Ortega-Mora, L. M. M. Ferreira, R. Celaya, and I. Ferre. 2007b. Anthelmintic and nutritional effects of heather supplementation on Cashmere goats grazing perennial ryegrass-white clover pastures. Journal of Animal Science 85:861-870.

Osoro, K., J. M. Vassallo, R. Celaya, and A. Martínez. 1999. Livestock production systems and the vegetation dynamics of Less Favoured Areas (LFAs): developing viable systems to manage semi-natural vegetation in temperate LFAs in Spain. In: J. P. Laker and J. A. Milne [EDs.]. Livestock production in the European less favoured areas. Proceedings of the 2nd Conference of the LSIRD Network; 3-5 December 1998; Bray, Dublin, Ireland. Aberdeen, Scotland, United Kingdom: Macaulay Land Use Research Institute. p. 133-143.
Peltzer, D. A., and M. Köchy. 2001. Competitive effects of grasses and woody plants in mixed-grass prairie. Journal of Ecology 89:519-527.

RADCLIFFE, J. E. 1986. Gorse - a resource for goats? New Zealand Journal of Experimental Agriculture 14:399-410.

Rigueiro-Rodríguez, A., M. R. Mosquera, R. Romero, M. P. González, and J. J. Villarino. 2005. Silvopastoral systems as a forest fire prevention technique. In: M. R. Mosquera-Losada, A. Rigueiro-Rodríguez, and J. McAdam [EDS.]. Silvopastoralism and sustainable land management. International Congress; 18-24 April 2004; Lugo, Spain. Wallingford, Oxfordshire, United Kingdom: CAB International. p. 380-387.

Rook, A. J., B. Dumont, J. Isselstein, K. Osoro, M. F. Wallisdevries, G. Parente, and J. MıLLs. 2004. Matching type of grazing animal to desired biodiversity outcomes-a review. Biological Conservation 119:137-150.

SAS InstituTE. 1999. SAS/STAT user's guide. Version 8. Cary, NC, USA: SAS Institute Inc.

SineiRo, F. 1982. Aspectos del uso ganadero del monte en Galicia para la producción de carne. Pastos 12:1-39.

Thompson, D. B. A., A. J. MacDonald, J. H. Marsden, and C. A. Galbraith. 1995. Upland heather moorland in Great Britain: a review of international importance, vegetation change and some objectives for nature conservation. Biological Conservation 71:163-178.

Vandvik, V., E. Heegaard, I. E. Måren, and P. A. Aarrestad. 2005. Managing heterogeneity: the importance of grazing and environmental variation on post-fire succession in heathlands. Journal of Applied Ecology 42:139149.

Wang, Z., AND L. A Goonewardene. 2004. The use of MIXED models in the analysis of animal experiments with repeated measures data. Canadian Journal of Animal Science 84:1-11.

WEBB, N. R. 1998. The traditional management of European heathlands. Journal of Applied Ecology 35:987-990.

WeLCH, D., AND D. SCOTt. 1995. Studies in the grazing of heather moorland in northeast Scotland. VI. 20-year trends in botanical composition. Journal of Applied Ecology 32:596-611.

ZaR, J. H. 1999. Biostatistical analysis. 4th ed. Upper Saddle River, NJ, USA: Prentice Hall. 929 p. 